\title{
Phytoregulators in the Reproductive and Productive Characteristics of Plants and Physicochemical Characteristics of 'Packham's Triumph' European Pears
}

\author{
Ana P. F. de Lima ${ }^{1}$, Marcos A. Giovanaz ${ }^{1}$, Priscila A. Amaral ${ }^{1}$, Renan Navroski ${ }^{1}$, \\ José C. Fachinello (in memorian) ${ }^{1} \&$ Marcelo B. Malgarim ${ }^{1}$ \\ ${ }^{1}$ Federal University of Pelotas, Capão do Leão, Rio Grande do Sul, Brazil \\ Correspondence: Renan Navroski, Federal University of Pelotas, Capão do Leão, Rio Grande do Sul, Brazil. \\ E-mail: navroski@outlook.com
}

Received: February 12, 2019

Accepted: March 14, 2019 Online Published: May 15, 2019

doi:10.5539/jas.v11n6p480

URL: https://doi.org/10.5539/jas.v11n6p480

The research is financed by Coordenação de Aperfeiçoamento de Pessoal de Nivel Superior (CAPES).

\begin{abstract}
The objective of this study was to evaluate the reproductive, productive and physicochemical characteristics of fruits (fruit volume and soluble solids) of 'Packham's Triumph' pear trees treated with different doses of phytoregulators. The experiment was carried out in the 2014/2015 and 2015/2016 cycles, using 1-naphthaleneacetic acid (NAA), 2-chloroethyl phosphonic acid (Etefon) and 6-Benzyladenine (BA) phytoregulators, each at doses of 200 and $300 \mathrm{ml} \mathrm{L}^{-1}$. The experimental design consisted of a randomized block with five replicates, where each experimental unit consisted of one plant. Significance was only found for soluble solids in the 2014/2015 harvest, observing that the highest mean was identified in plants treated with 300 $\mathrm{ml} \mathrm{L}^{-1}$ Etefon, $\left(15^{\circ}\right.$ Brix), while the lowest soluble solids content was observed with the dose of $200 \mathrm{mg} \mathrm{L}^{-1}$ of NAA, (11 ${ }^{\circ}$ Brix); in the 2015/2016 crop, the highest number of inflorescences of the year was identified in plants treated with $200 \mathrm{ml} \mathrm{L}^{-1}$ of Etefon, (1.66) and the lowest value for the treatment with $300 \mathrm{ml} \mathrm{L}^{-1}$ of BA, (0.17). Effective fruiting in the value of $58.33 \%$ was also observed and verified for the plants treated with $300 \mathrm{mg} \mathrm{L}^{-1}$ of NAA, differing from all except from $200 \mathrm{ml} \mathrm{L}^{-1}$ BA. Only the plant growth regulator, NAA, at the dose of 200 $\mathrm{mg} \mathrm{L}^{-1}$ provides low content of soluble solids in the fruits and Etefon $300 \mathrm{mg} \mathrm{L}^{-1}$ provides high content of solids solubles. The lowest number of branch inflorescences of the year was in plants treated with 6-Benzyladenine at a dose of $300 \mathrm{ml} \mathrm{L}^{-1}$ and the highest at a dose of Etefon $200 \mathrm{mg} \mathrm{L}^{-1}$. The NAA dose of $300 \mathrm{mg} \mathrm{L}^{-1}$ and 6-Benzyladenine dose of $200 \mathrm{ml} \mathrm{L}^{-1}$ had greater effective fruiting, but not did not reflect on the production per plant and productive efficiency. There was no benefit observed in the return bloom with the application of phytoregulators. Besides, no benefits were observed in the return bloom with the application of phytoregulators.
\end{abstract}

Keywords: Benzyladenine, Etephon, flowering, naphthaleneacetic acid, plant hormone, Pyrus communis

\section{Introduction}

Due to its pleasant taste and nutritional value, the pear (Pyrus spp.) is one of the most popular fruits in the world (Simirgiotis et al., 2016). Despite the fact that consumption is high and domestic production does not support such demand, pear cultivation is not considered very expressive in Brazil, representing only $0.5 \%$ of the total temperate fruits produced in the country (Fachinello et al., 2011).

For the success of any agricultural activity, it is paramount to know the physical environment factors that affect the physiological and phenological processes of plants (Morais et al., 2008). In the cultivation of pear trees, some obstacles to the dissemination of cultivation and growth in area have been reported by several authors. Temperature fluctuations, insufficiency of winter chill hours required by cultivars, water stress and nutritional stress, with emphasis on carbohydrates and micronutrients (Veríssimo et al., 2004) are among the main factors of the physical environment, besides disease, entomosporiosis (Nunes \& Alves, 2012) and bacterial contamination (Pseudomonas sp.) (Rommel et al., 2010). In addition to the aforementioned factors, there are also intrinsic issues of the plant such as vegetative vigor, type of rootstock, bud abortion, requirement in cold hours, lack of 
cultivars adapted to edaphoclimatic conditions (Fachinello et al., 2011) and the floral biology (Veríssimo et al., 2004).

Therefore, the formation of a flower bud is one of the most important physiological processes in the upper plants (Kittikorn et al., 2010). For the process of flower development, the plant goes through three stages: induction, initiation and floral differentiation. It is in the induction phase that floral development is activated (Faust, 1989) and this activation is strongly expressed at eight weeks after full bloom (two weeks before floral initiation), gradually decreasing over time (Francescatto, 2014).

In view of the above, the objective of this study was to evaluate the reproductive and productive characteristics of the 'Packham's Triumph' european pear, treated with different concentrations of phytoregulators during the physiological process of floral induction.

\section{Material and Methods}

The experiment was carried out in a commercial orchard, located at $28^{\circ} 4^{\prime} 20^{\prime \prime} \mathrm{S}, 51^{\circ} 16^{\prime} 32^{\prime \prime} \mathrm{W}$ and $744 \mathrm{~m}$ altitude, in the municipality of Ipê, Rio Grande do Sul, Brazil, during the 2014/2015 and 2015/2016 cycles. A 'Packham's Triumph' pear tree cultivar grafted on the BA-29 quince rootstock and FT filter was used. The orchard density is 4,081 plants $\mathrm{ha}^{-1}$, with a spacing of $3.5 \mathrm{~m}$ between rows and $0.7 \mathrm{~m}$ between plants, conducted in a free system implanted in 2011.

The experiment consisted of seven treatments: plants without application (control), plants treated with 1-naphthaleneacetic acid (NAA) at doses of 200 and $300 \mathrm{mg} \mathrm{L}^{-1}$; 2-chloroethyl phosphonic acid (Etefon) at doses of 200 and $300 \mathrm{ml} \mathrm{L}^{-1}$ and 6-benzyladenine (BA) at doses of 200 and $300 \mathrm{ml} \mathrm{L}^{-1}$. All doses were calculated from the active ingredient.

The treatments were carried out once a week over five weeks, with the first application at 30 days after full bloom. The applications were carried out by spraying, using gasoline backpack sprayer with a mean tank-mix volume of approximately $1,000 \mathrm{~L} \mathrm{ha}^{-1}$. In all treatments, mineral oil (Silwet ${ }^{\circledR}$ ) $0.1 \%$ was added.

In both development cycles the following variables were evaluated: number of inflorescences per branch of the year, effective fruiting $(\%)$, return bloom (\%), production per plant $\left(\mathrm{kg} \mathrm{plant}^{-1}\right)$, average fruit mass, productive efficiency $\left(\mathrm{kg} \mathrm{cm}^{2}\right.$ plant $\left.{ }^{-1}\right)$, fruit volume $\left(\mathrm{cm}^{3}\right)$ and soluble solids $\left({ }^{\circ}\right.$ Brix $)$.

In order to count the number of branch inflorescences of the year, six branches per plant were counted, in these branches the effective fruiting was verified, counting the number of fruits remaining after 30 days of full flowering, the same was determined by the relation (number of fruits $\times 100$ )/(number of branch inflorescences of the year $\times 8$ flowers).

The return bloom was estimated by counting the number of branch inflorescences of the year (from the same branches of the above-mentioned variables) in the flowering following the application of plant growth regulators correlating with the count of the previous year. Thus, (count of inflorescences of the branch of the year $\times$ $100) /($ count of branch inflorescences of the year for the previous year).

Regarding the production variables, the total mass produced per plant was verified from the harvested fruits, which refers to the production per plant.

The average fruit mass was estimated by means of the production per plant and the number of fruits harvested in these same plants. The productive efficiency was calculated by the relation between the yield per plant and the area of the trunk section of the cultivar canopy.

In both variables, a sample of 10 fruits per experimental unit was used. The volume of the fruit was determined from the formula, in $\mathrm{cm}^{3}=\left(4 / 3 \pi \mathrm{r}^{3}\right)+15$, where the number $\pi$ is a mathematical proportion, $r$ is the fruit radius and 15 is the volume of the 'neck' of the fruit according to methodology established by Elkins et al. (2007). A bench refractometer was used to measure the soluble solids of the fruits and the evaluation was made from the juice of 10 fruits of the samples of each experimental unit.

The experimental design was in randomized blocks with five replicates. The experimental unit consisted of a plant, using the lateral plants as a border. The results were submitted to analysis of variance (ANOVA) and when significant, averages were compared using Tukey's test $(\mathrm{p} \leq 0.05)$.

\section{Results and Discussion}

In Table 1, it can be observed that in the 2014/2015 cycle, only the soluble solids content and the productive efficiency presented a response to the treatments. 
Table 1. Number of branch inflorescences of the year (NIR), production per plant (PP, Kg plant ${ }^{-1}$ ), average fruit mass (MUF, g), productive efficiency (EP, $\mathrm{Kg} \mathrm{cm}^{2}$ plant $\left.^{-1}\right)$, fruit volume $\left(\mathrm{VF}, \mathrm{cm}^{3}\right)$, soluble solids $\left(\mathrm{SS},{ }^{\circ} \mathrm{Brix}\right)$ of Packham's Triumph pear tree as a function of the doses of NAA, Etefon and 6-Benzyladenine (BA) in the development cycles of 2014/2015 and 2015/2016, Ipê/RS

\begin{tabular}{|c|c|c|c|c|c|c|}
\hline Treatment & NIR & $\mathrm{PP}$ & MUF & $\mathrm{EP}$ & VF & SS \\
\hline \multicolumn{7}{|l|}{ Cycle 2014/2015 } \\
\hline Control & $0.05 \mathrm{~ns}$ & $3.00 \mathrm{~ns}$ & $194.70 \mathrm{~ns}$ & $19.50 \mathrm{~B}$ & $214.53 \mathrm{~ns}$ & $12.50 \mathrm{AB}$ \\
\hline NAA $200 \mathrm{mg} \mathrm{L}^{-1}$ & 0.33 & 0.90 & 177.77 & $16.12 \mathrm{~B}$ & 225.36 & $11.00 \mathrm{C}$ \\
\hline NAA $300 \mathrm{mg} \mathrm{L}^{-1}$ & 0.33 & 1.09 & 236.00 & $33.85 \mathrm{~A}$ & 247.12 & $14.00 \mathrm{AB}$ \\
\hline Etefon $200 \mathrm{mg} \mathrm{L}^{-1}$ & 0.89 & 1.60 & 208.16 & $23.69 \mathrm{AB}$ & 252.53 & $14.60 \mathrm{~A}$ \\
\hline Etefon $300 \mathrm{mg} \mathrm{L}^{-1}$ & 1.27 & 5.30 & 170.93 & $17.30 \mathrm{~B}$ & 193.23 & $15.00 \mathrm{~A}$ \\
\hline BA $200 \mathrm{mg} \mathrm{L}^{-1}$ & 0.44 & 2.38 & 229.58 & $22.15 \mathrm{AB}$ & 225.36 & $14.26 \mathrm{AB}$ \\
\hline BA $300 \mathrm{mg} \mathrm{L}^{-1}$ & 0.72 & 3.21 & 241.92 & $22.05 \mathrm{AB}$ & 266.52 & $14.20 \mathrm{AB}$ \\
\hline Mean & 0.64 & 2.50 & 208.44 & 22.09 & 229.86 & 13.65 \\
\hline \multicolumn{7}{|l|}{ Cycle 2015/2016 } \\
\hline Control & $0.75 \mathrm{AB}$ & $3.55 \mathrm{~ns}$ & $258.93 \mathrm{~ns}$ & $22.06 \mathrm{~ns}$ & $332.36 \mathrm{~ns}$ & $13.80 \mathrm{~ns}$ \\
\hline NAA $200 \mathrm{mg} \mathrm{L}^{-1}$ & $0.83 \mathrm{AB}$ & 2.70 & 335.59 & 23.73 & 244.11 & 13.06 \\
\hline NAA $300 \mathrm{mg} \mathrm{L}^{-1}$ & $0.27 \mathrm{~B}$ & 2.44 & 205.24 & 18.08 & 268.71 & 13.66 \\
\hline Etefon $200 \mathrm{mg} \mathrm{L}^{-1}$ & $1.66 \mathrm{~A}$ & 0.98 & 247.73 & 24.59 & 273.49 & 15.13 \\
\hline Etefon $300 \mathrm{mg} \mathrm{L}^{-1}$ & $0.95 \mathrm{AB}$ & 0.64 & 200.55 & 15.52 & 217.25 & 15.13 \\
\hline BA $200 \mathrm{mg} \mathrm{L}^{-1}$ & $0.33 \mathrm{~B}$ & 1.41 & 212.35 & 15.27 & 253.98 & 14.40 \\
\hline BA $300 \mathrm{mg} \mathrm{L}^{-1}$ & $0.17 \mathrm{C}$ & 1.89 & 204.22 & 17.06 & 243.93 & 14.26 \\
\hline Mean & 0.71 & 1.94 & 237.81 & 19.86 & 261.98 & 14.23 \\
\hline
\end{tabular}

Note. Means followed by upper case letters do not differ by Tukey test at $5 \%$ probability of error. NS: not significant by the Tukey test at $5 \%$ probability of error.

A higher sugar content was observed when $200 \mathrm{ml} \mathrm{L}^{-1}$ of Etefon was applied, but did not differ from the control, or from $300 \mathrm{mg} \mathrm{L}^{-1}$ of NAA, 200 and $300 \mathrm{ml} \mathrm{L}^{-1}$ of Etefon and both doses of 6-Benzyladenine. All other treatments differed from the NAA $200 \mathrm{mg} \mathrm{L}^{-1}$ concentration, which presented the lowest mean $\left(11^{\circ} \mathrm{Brix}\right)$. Gala apple plants treated with doses of 5 and $10 \mathrm{mg} \mathrm{L}^{-1}$ of Thiadizuron (phenylurea with cytokinetic effect) did not present a significant difference between the doses, and the averages were 12 and $11.8 \%$ of soluble solids respectively (Petri et al., 2001). In the 'Abate Fetel' pear tree, Luz (2016), there was also no difference between vigor control treatments, observing a mean of $13.3{ }^{\circ}$ Brix for the plant growth regulator, Moddus $\left(1,600 \mathrm{mg} \mathrm{L}^{-1}\right)$. Carra et al. (2016) used Calcium Prohexadione and evaluated the quality of stored fruits and concluded that it did not significantly alter the qualitative attributes, among them the soluble solids of 'Le Conte' pears. Furthermore, evaluating the same attributes and phytogulator, Carra et al. (2017) did not observe changes in the quality of 'Smith' pears.

The treatment that stood out in relation to the productive efficiency was that of $200 \mathrm{mg} \mathrm{L}^{-1}$ concentration of NAA with a mean of $33.85 \mathrm{Kg} \mathrm{cm}^{2}$ plant $^{-1}$, but it did not differ from $200 \mathrm{ml} \mathrm{L}^{-1}$ of Etefon $\left(23.69 \mathrm{Kg} \mathrm{cm}^{2}\right.$ plant $\left.^{-1}\right)$ nor from both concentrations of 6-Benzyladenine $\left(22.15 \mathrm{Kg} \mathrm{cm}^{2}\right.$ plant $^{-1}$ for $200 \mathrm{ml} \mathrm{L}^{-1}$ and $22.05 \mathrm{Kg} \mathrm{cm}^{2}$ plant $^{-1}$ for $300 \mathrm{ml} \mathrm{L}^{-1}$ ). Machado (2011) reports that in plants with intermediate vigor, there is a better balance between vegetative and reproductive part, conferring a greater productive efficiency in varieties of European pear trees. The same author also describes reduced vegetative growth of 'Clapp's Favorite' plants grafted on quince 'EMA', at spacings of 1 and 0.5 meters, due to the greater stress due to incompatibility with the EMA graft, giving rise to little reproductive material (toasts and spurs), affecting the productive potential of the plant, providing low productive efficiency.

In the 2015/2016 cycle, a statistical difference was only observed for the number of branch inflorescences of the year and effective fruiting variables.

For the number of branch inflorescences of the year, in 2015/2016, it was verified that in the plants treated with $200 \mathrm{ml} \mathrm{L}^{-1}$ of Etefon, the largest number (1.66) was obtained, differing only from the concentrations of $200 \mathrm{ml}$ $\mathrm{L}^{-1}$ of Etefon and $300 \mathrm{ml} \mathrm{L}^{-1}$ of 6-Benzyladenine, which presented, 1.66 and 0.17 , respectively. The control, 200 $\mathrm{mg} \mathrm{L}^{-1}$ of NAA, $300 \mathrm{ml} \mathrm{L}^{-1}$ of Etefon and 200 and $300 \mathrm{ml} \mathrm{L}^{-1}$ of 6-Benzyladenine did not differ among 
themselves, presenting values of $0.75,0.83,0.95,0.33$, respectively. The lowest number of flower bunches was observed for the treatment with $300 \mathrm{ml} \mathrm{L}^{-1}$ of 6-Benzyladenine, which presented 0.17 branch inflorescences of the year, thus differing from the other treatments. Petri et al. (2001) found no difference in the number of inflorescences of 'Gala' apple trees treated with 5 and $10 \mathrm{mg} \mathrm{L}^{-1}$ of Thiadizuron over seven years, which shows that there was no inhibition of flowering in the cycle after the application of this plant growth regulator. Possibly, the concentrations used by this author were insufficient to cause the desired effect, which proves to be a vast field to be explored.

Even in the 2015/2016 cycle, greater effective fruiting was observed in plants treated with $300 \mathrm{mg} \mathrm{L}^{-1}$ of NAA, $(58.33 \%)$, this result differed from all except from $200 \mathrm{ml} \mathrm{L}^{-1}$ of 6-Benzyladenine (Figure 1). The low effective fruiting is one of the main technical problems associated to the pear tree cultivation, characterizing low productive rates of the crop. The climatic conditions and the low synchronization of the flowering between cultivars, lead to a low and irregular production (Hawerroth et al., 2011). In the 2014/2015 cycle, there was no influence of treatments for this variable. Luz (2016), using physical methods for growth control to induce flowering in 'Abate Fetel' and 'Carrick' pears, obtained a fruiting average of $1 \%$ and $3 \%$. This same author reinforces that pear trees with low flowering need an effective fruiting higher than $30 \%$. The Asian 'Shinseiki' pear tree presented an effective fruiting rate above $158 \%$ when treated with Thiadizuron, whereas the control presented 65.6\% (Hawerroth et al., 2011). Petri et al. (2001) report that Thiadiziron also increased the effective fruit yield to $128.2 \%$ in 'Packham's Triumph' pear trees, but the effect is variable according to the cultivar, having a greater effect on Japanese pears (Pyrus serotina) which can be attributed to the pollination problem presented by the cultivars of this species.

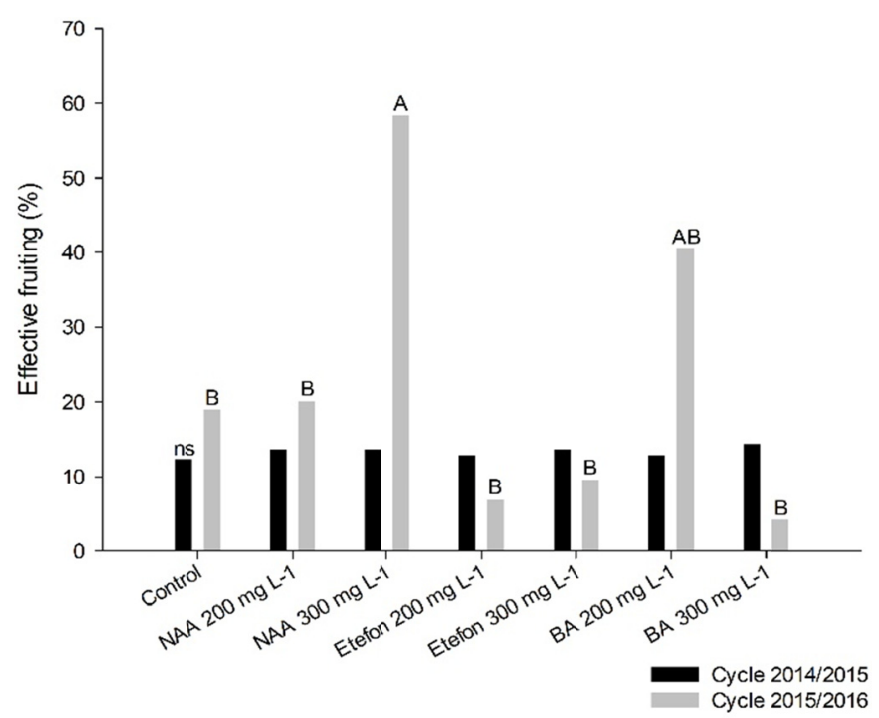

Figure 1. Effective fruiting (\%) of 'Packham's Triumph' pear tree as a function of the doses of NAA, Etefon and 6-Benzyladenine in the 2014/2015 and 2015/2016 development cycles, Ipê/RS

Regarding the return bloom, no statistical difference was observed in both evaluation years (Figure 2). In the 'Le Conte' pear, this parameter was not affected by the use of Calcium Prohexadione (Carra et al., 2016). Pasa and Einhorn (2017) did not observe effect of Prohexadione of Calcium in the return bloom in 'Strakinson' pear, nor in 'Carrick', 'Packham's Triumph' and 'William's' pears with the use of Calcium Prohexadione (Pasa et al., 2016). In 'Abate Fetel' and 'Carrick', the application of Moddus ${ }^{\circledR}$ reduced the return bloom compared to the control plants (Luz, 2016), and this can be justified by the affirmation of Carra et al. (2016), in which there is an inverse relationship between fruiting and return bloom. 


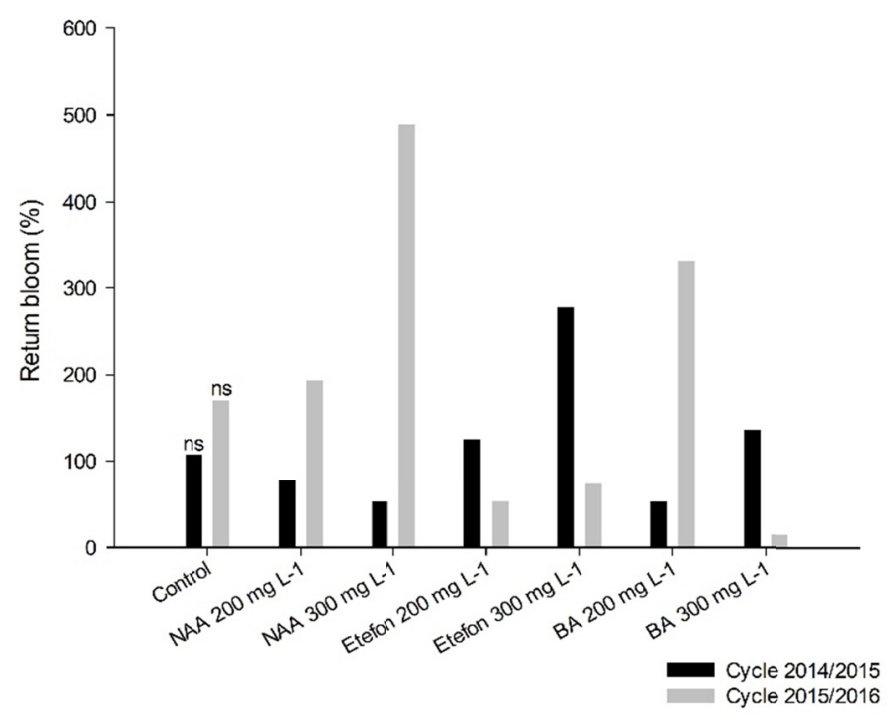

Figure 2. Return bloom (\%) of 'Packham's Triumph' pear tree as a function of the doses of NAA, Etefon and Maxcel in the development cycles of 2014/2015 and 2015/2016, Ipê/RS

\section{Conclusions}

Only the plant growth regulator, NAA, at the dose of $200 \mathrm{mg} \mathrm{L}^{-1}$ provides low content of soluble solids in the fruits and Etefon $300 \mathrm{mg} \mathrm{L}^{-1}$ provides high content of solids solubles.

The lowest number of branch inflorescences of the year was in plants treated with 6-Benzyladenine at a dose of $300 \mathrm{ml} \mathrm{L}^{-1}$ and the highest at a dose of Etefon $200 \mathrm{mg} \mathrm{L}^{-1}$

The NAA dose of $300 \mathrm{mg} \mathrm{L}^{-1}$ and 6-Benzyladenine dose of $200 \mathrm{ml} \mathrm{L}^{-1}$ had greater effective fruiting, but not did not reflect on the production per plant and productive efficiency.

There was no benefit observed in the return bloom with the application of phytoregulators.

\section{References}

Carra, B., Pasa, M. S., Fachinello, J. C., Spagnol, D., Abreu, E. S., \& Giovanaz, M. A. (2016). Prohexadione calcium affects shoot growth, but not yield components of 'Le Conte' pear in warm-winter climate conditions. Scientia Horticulturae, 209, 241-248. https://doi.org/10.1016/j.scienta.2016.06.036

Carra, B., Spagnol, D., Abreu, E. S. D., Pasa, M. D. S., Silva, C. P. D., Hellwig, C. G., \& Fachinello, J. C. (2017). Prohexadione calcium reduces vegetative growth and increases fruit set of 'Smith' pear trees, in Southern Brazil. Bragantia, 76, 360-371. https://doi.org/10.1590/1678-4499.298

Elkins, R. B., Ende, B. V. D., \& Beutel, J. (2007). Vegetative Growth and Fruit Development. In M. J. Mitcham, R. B. Elkins (Eds.), Pear: production and handling manual (pp. 51-62). Oakland: University of California.

Fachinello, J. C., Pasa, M. S., Schmtiz, J. D., \& Betemps, D. L. (2011). Situação e perspectiva da fruticultura de clima temperado no Brasil. Revista Brasileira de Fruticultura, 33, 109-120. https://doi.org/10.1590/S010029452011000500014

Faust, M. (1989). Physiology of temperate zone fruit trees. New York: Wiley.

Francescatto, P. (2014). Desenvolvimento das estruturas reprodutivas de macieira (Malus domestica Boskh.) sob diferente condições climáticas: Da formação do fruto à colheita (p. 239, Tese (Doutorado), Universidade Federal de Santa Catarina).

Hawerttoh, F. J., Herter, F. G., Fachinello, J. C., Petri, J. L., Prezotto, M. E., Haas, L. E., \& Pretto, A. (2011). Aumento da produção de pereira asiática pelo uso de fitorreguladores. Ciência Rural, 41(10), 1750-1754. https://doi.org/10.1590/S0103-84782011001000012

Kittikorn, M., Okawa, K., Ohara, H., Yokoyama, M., Ifuku, O., Yosida, S., \& Kondo, S. (2010). 9,10- Ketol Octadecadienoic Acid (Koda) levels and flower a bud formarion in apple. Acta Horticulturae, 884, 133-137. https://doi.org/10.17660/ActaHortic.2010.884.14 
Luz, A. R. (2016). Técnicas de redução de vigor e aumento da frutificação de pereiras europeias (p. 163, Tese (Doutorado), Universidade do Estado de Santa Catarina).

Machado, B. D. (2011). Aspectos vegetativos e produtivos de cultivares copa de pereira europeia com combinações de porta enxertos (Dissertação (Mestrado), Universidade do Estado de Santa Catarina, Lages).

Morais, H., Marur, C. J., Caramori, P. H., Koguishi, M. S., \& Gomes, J. C. (2008). Desenvolvimento de gemas florais de cafeeiros em condições de sombreamento. Pesquisa Agropecuária Brasileira, 43(4), 465-472. https://doi.org/10.1590/S0100-204X2008000400004

Nunes, C. C., \& Alves, S. A. M. (2012). Elaboração e validação de escala diagramática para quantificação da severidade de entomosporiose em folhas de Pereira. Summa Phytopathology, 38(3), 239-244. https://doi.org/10.1590/S0100-54052012000300011

Pasa, M. S., Fachinello, J. C., Da Rosa Júnior, H. F., De Franceschi, É., Herter, F. G., Da Silva, C. P., \& De Souza, A. L. K. (2016). Prohexadione calcium controls shoot growth of pear trees under mild winter conditions. Current Agricultural Science and Technology, 22, 40-49.

Pasa, M. S., \& Einhorn, T. (2017). Prohexadione calcium on shoot growth of 'Starkrimson' pear trees. Pesquisa Agropecuária Brasileira, 52, 75-83. https://doi.org/10.1590/s0100-204×2017000200001

Petri, J. L., Schuck, E., \& Leite, G. B. (2001). Efeito do Thiadizuron (TDZ) na frutificação de fruteiras de clima temperado. Revista Brasileira de Fruticultura, 23(3), 513-517. https://doi.org/10.1590/S0100-294520010 00300012

Rommel, C., Valdebenito-Sanheuza, R. M., \& Duarte, V. (2010). Detecção de bactérias associadas a gemas de pereiras europeias no Rio Grande do Sul. Tropical Plant Pathology, 35(6), 360-367. https://doi.org/10.1590/ S1982-56762010000600004

Simirgiotis, M. J., Quispe, C., Bosquez, J., Arche, C., \& Sepulveda, B. (2016). Fast detection of phenolic compounds in extracts of Easter pear (Pyrus communis) from the Atacama Desert by ultra high-performance liquid chromatography and mass spectrometry (UHPLC/Orbitrop/MS/MS). Molecules, 21(92), 1-14. https://doi.org/10.1590/10.3390/molecules21010092

Verissimo, V., Eter, F. G., Rodrigues, A. C., Gardin, J. P., \& Silva, J. B. (2004). Caratecterização de gemas florais (Pyrus sp.) relacionada ao abortamento floral. Revista Brasileira de Fruticultura, 26(2), 193-197. https://doi.org/10.1590/S0100-29452004000200003

\section{Copyrights}

Copyright for this article is retained by the author(s), with first publication rights granted to the journal.

This is an open-access article distributed under the terms and conditions of the Creative Commons Attribution license (http://creativecommons.org/licenses/by/4.0/). 